\title{
Trumpeter Swan Cygnus \\ buccinator range expansion \\ programs in the northern \\ Rocky Mountains, USA
}

\author{
RUTH SHEA, DAVE C. LOCKMAN and \\ CARL D. MITCHELL
}

\begin{abstract}
We review the status of Trumpeter Swans in the northern Rocky Mountains of the United States. Limited winter habitat appears to be inhibiting population growth. To alleviate problems of overcrowding, and to meet long-term population goals, experiments in range expansion procedures began in 1986. Overall, relocated Trumpeter Swans have survived well and acted as decoys for other swans. We discuss the use of various age classes and release methods.
\end{abstract}

Trumpeter Swans Cygnus cygnus buccinatorwere extirpated from most of their historic range due to over-harvest by commercial, subsistence and sport hunting, and loss of habitat (Banko 1960). As populations were depleted, most migration to southerly and coastal winter habitats was eliminated (Gale et al. 1987). In 1932, the only known wild Trumpeter Swans were 69 birds found in the Tristate area where the states of Montana, Idaho and Wyoming share common borders.

The resident population of Trumpeter $S$ wans (the Tristate Subpopulation), has increased between 1932 and 1989 but population levels have fluctuated considerably (Mitchell et al. 1991). It reached a maximum of 641 in 1958, declined to 392 in 1986 and stands at 565 in 1989.

The resident Tristate Subpopulation (TSP) is joined in winter by the migratory Interior Canada Subpopulation(ICSP). Together they are known as the Rocky Mountain Population (RMP). This population now totals 1,743 . The RMP has doubled since 1977 (Gale et al. 1987).

The historic elimination of other migratory patterns underlies the RMP's current restricted winter distribution. The population is very vulnerable to adverse factors on their winter habitat. Potential problems include depletion of limited aquatic forage, disease transmission, water pollution, inadequate water flows and ice formation and disturbance from increasing human populations. Inadequate winter habitat within the current range and failure to discover and use existing habitat outside the current range is probably preventing the RMP from expanding to its full potential.

In order to allow continued population growth and reduce vulnerability, wildlife managers decided to actively expand the wintering range of the RMP. The range expansion goals and objectives are outlined in the North American Management Plan for Trumpeter Swans (Anonymous 1984). They are to maintain a wintering population of at least 1,100 Trumpeter Swans in currently occupied range and to establish two new wintering sites for 50-150 swans by 1990 and two additional sites capable of supporting $50-150$ swans by 2,000 .

This paper aims to (1) present the rationale for Trumpeter Swan range expansion in the Tristate area, (2) describe efforts and evaluate their success, and (3) present recommendations on swan relocation techniques (Scott \& Carpenter 1987).

\section{Study Area}

Four areas are central to the present range expansion project. Red Rock Lakes National Wildlife Refuge (RRLNWR) at $44^{\circ} 38^{\prime} \mathrm{N}$, $111^{\circ} 45^{\prime} \mathrm{W}$ in Montana is a 17,200 ha marsh/ upland complex. It is the source of most of the transplant swans.

Three transplant sites have been used to date. They are all at lower elevations and south of RRLNWR. Grays Lake National Wildlife Refuge (GLNWR) is a 8,900 ha marsh located at $1920 \mathrm{~m}$ at $43^{\circ} 00^{\prime} \mathrm{N}, 111^{\circ} 27^{\prime} \mathrm{W}$, in Idaho. The Fort Hall Bottoms ( 1336 m elevation) is a 10,120 ha river and marsh complex located on the Snake River in Idaho at $43^{\circ} 05^{\prime} \mathrm{N}, 112^{\circ} 38^{\prime} \mathrm{W}$. The Salt River valley ( $1770 \mathrm{~m}$ elevation) is a riverine system in western $W$ yoming $\left(42^{\circ} 30^{\prime} \mathrm{N}\right.$, $111^{\circ} 00^{\prime} \mathrm{W}$ ). 


\section{Methods}

Release sites were selected because of historical Trumpeter Swan use (Burgess 1986) and site evaluations indicating that required habitat characteristics were present (Lockman et al. 1987).

Cygnets ( $<12$ months old), yearlings (12-24 months old) and adults ( $>24$ months old) were used for experimental releases. Cygnets were either hand-reared with or without exposure to adult Trumpeter Swans or were captured from wild broods. Most yearling swans were captured during their flightless moult at RRLNWR. Flightless adults had been rehabilitated due to prior injury. All wild swans were marked with aluminium tarsus rings and either wrap-around patagial markers or collars.

Cygnets were released with adults using "soft release" techniques, where swans are placed in enclosures and allowed to leave on their own when fledged. Yearlings were "hard released," i.e., they were placed into new sites directly after transport and allowed to swim free.

Post-release observations of behaviour and movements were made by ground based observers. Four aerial surveys each year were made to locate dispersing swans in 1988 and 1989.

\section{Results}

Two groups of cygnets ( 5 in 1987 and 7 in 1988) were placed with adults on the Salt River in western Wyoming. Of these, four were killed by accident, predation and intraspecific aggression. Eight surviving swans remain in the area and have acted as decoys for wild swans.

Three different yearling swan groups have been released at GLNWR. Two siblings from Wyoming were moved there in 1986, 13 yearlings from RRLNWR were moved in 1988 and 15 were moved from RRLNWR in 1989. Five of the swans from the 1988 release are dead and two are unaccounted for. Many of the surviving swans released in 1988 have been found wintering on the Salt River. Five of the swans from the 1988 release returned to GLNWR in the spring of 1989 . Five swans from the 1989 release have been observed on the Salt River in Wyoming, and four have moved $500 \mathrm{~km}$ southwest to Fish Springs National Wildlife Refuge in Utah. Six swans from this release are unaccounted for.

In 1988, 15 yearling Trumpeter Swans from RRLNWR were translocated to the Ft. Hall Bottoms. These birds dispersed widely after regaining flight. At least five died, and eight are unaccounted for. Four rehabilitated Trumpeter Swans rescued during the winter of 1988-89 were moved to a small enclosure on Ft. Hall Bottoms in September 1989. On 5 November all four were killed by a coyote Canis latrans. Necropsy revealed extremely heavy parasite infestation and extreme emaciation.

\section{Discussion}

The main goal is to expand the winter distribution of the RMP. We expect this to benefit the population by (1) protecting current habitats from degradation caused by overuse and (2) reducing impacts of a local catastrophe. By wintering birds over a larger area, we also hope to re-populate some former breeding habitats and increase overall productivity, as Trumpeter Swans encounter better winter conditions and obtain better pre-nesting food resources in more hospitable climates.

All age classes are suitable for range expansion efforts. Project goals, habitat types and logistical considerations will dictate which age class is most suitable for a particular release. Different procedures must be used for the different age classes.

Cygnets are most suitable for release in yearround habitat. They do not possess strong pioneering instincts. Cygnets should be released only with flightless adults as "mentors". Best success with cygnets occurs with soft releases. Cygnets released in year-round habitat can be used to decoy other swans into an area.

Yearlings are suitable for release in yearround habitat and where limited pioneering is desired. Yearlings have sufficient experience to survive without adult guidance if placed in good quality habitat. They may act as decoys in yearround habitat. We used yearlings, released on summer range, in conjunction with cygnet decoys on nearby winter range, to establish a short migration.

Adults are generally suited for range expansion projects only when permanently flightless. They often function well as surrogate parents for cygnets. However, they should be carefully chosen for this role, as some older birds do not accept cygnets. By separating cygnets and adults in adjacent enclosures, the cygnets learn by example while remaining protected from adult aggression. Flightless adults placed on yearround habitat also act as decoys.

Griffith et al. (1989) found no association between hard and soft releases and translocation 
success. However, when circumstances dictate the use of a hard-release, we suggest that yearlings or adults should be used. Trumpeter Swans used in hard releases should be temporarily flightless, to restrain immediate tendencies to disperse, and to force birds to acclimate to the new surroundings.

Relocated Trumpeter Swans have demonstrated an ability and inclination to travel, overland if necessary. The release site should be large enough to accommodate considerable travel by water so that the relocated birds are unable to leave the wetland immediately. If swans are released on small sites, physical barriers may be necessary to prevent overland dispersal.

Whenever possible, release site habitat should be similar to the swans previous habitat. For example, Ft. Hall consists primarily of small spring fed streams, oxbow meanders and a large river. Trumpeter Swans released there in 1988 were moved from large, open lakes and marshes. We believe that the dispersal of these birds from the release site may be due in part to an inability or unwillingness to accept the different habitat. If Trumpeter Swans are to be relocated to different habitat types, cygnets probably offer the highest chance for success.

Control of human disturbance to Trumpeter Swans is vital. Older swans that have not been exposed to humans do not tolerate disturbance. This is especially true of areas open to wildfowl hunting. If cygnets are used for release, they can be acclimated to various degrees of human presence.

Involving local landowners and media in the releases was helpful in getting the local populace to accept the programs. Local media coverage resulted in several sightings of dispersed or dead swans. Media accounts, local contacts and posters placed in the release areas all acted to reduce swan mortality by vandals or uninformed hunters.

We found collars with distinct symbolic or alpha-numeric codes to be preferable to wraparound patagial markers (Young \& Kochert 1987). Collars are more easily observed and read than patagial markers. Patagial markers did not cause feather wear or other problems for the marked swans. Several patagial markers were lost. Experiments with affixing patagial markers, marker size, etc. are needed. We plan to use collars for most of our marking in future releases. However, collars are not appropriate for cygnets in this climate. Adults have been observed pecking ice accumulations off collars in winter but cygnets are not always able to keep their collars ice-free.

Refinements in technique and procedure are continuing. Our plans incorporate most of the factors Griffith et al. (1989) associated with translocation success. These include using herbivorous, wild-caught native species, from a stable high density source population, released in high quality habitat within historical range, with few competitors present. With continued range expansion efforts, in conjunction with other ongoing management programs, we expect to meet the population goals outlined in the North American Management Plan for Trumpeter Swans (Anonymous 1984).

\section{References}

Anonymous. 1984. North American Management Plan for Trumpeter Swans. Unpublished report. $62 \mathrm{pp}$.

Banko, W.E. 1960. The Trumpeter Swan. Its history, habits, and population in the United States. North American Fauna No. 63 U.S. Fish and Wildlife Service, Washington, D.C. 189 pp.

Burgess, H. 1986. Potential Trumpeter Swan restoration. pp. 97-111 In: D. Compton, (ed.) Proc. and papers 9th Trumpeter Swan Soc. Conf. Omni Press. Madison, WI $132 \mathrm{pp}$.

Gale, R.S., Garton, E.O. \& Ball, I.J. 1987. The history, ecology and management of the Rocky Mountain Population of Trumpeter Swans. Unpublished manuscript. $314 \mathrm{pp}$.

Griffith, B., Scott, J.M., Carpenter, J.W. \& Reed, C. 1989. Translocation as a species conservation tool: status and strategy. Science 245:477-480.

Lockman, D.C., Wood, R., Burgess, H., Burgess, R. \& Smith, H. 1987. Progress report. Rocky Mountain Trumpeter Swan Population. Wyoming Flock 1982-1986. Unpublished report. Wyoming Game and Fish Department, Cheyenne, WY. 73 pp.

Mitchell, C.D., Shea, R. \& Lockman, D.C. 1991. Demographic analyses of a Trumpeter Swan Cygnus buccinator population in western U.S.A. In: J. Sears \& P.J. Bacon (eds.) Proc. 3rd Int. Swan Symp. Oxford, 1989. Wildfowl (Special Supplement no.1).

Scott, J.M. \& Carpenter, J.W. 1987. Release of captive-reared or translocated endangered birds: what do we need to know? Auk 104(3):544-545. 
Young, L.S. \& Kochert, M.N. 1987. Marking techniques. p. 125-156 In: B.A. Giron-Pendleton, B.A. Millsap, K.W. Cline, \& D.M. Bird, (eds.) Raptor Management Techniques Manual. National Wildlife Federation Scientific and Technical Series No. 10. National Wildlife Federation, Washington, D.C. 420 pp.

Ruth Shea, Idaho Department of Fish and Game, 1515 Lincoln Road, Idaho Falls, Idaho 83401 USA Dave C. Lockman, Wyoming Game and Fish Department, 5400 Bishop Boulevard, Cheyenne, Wyoming 82002 USA

Carl D. Mitchell, U.S. Fish and Wildlife Service, Red Rock Lakes National Wildlife Refuge, Monida Star Route, Box 15, Lima, Montana 59739 USA 